\title{
Impacts of the Monetary Policy on the Stock Markets: Case Studies in Vietnam and Shenzhen China
}

\author{
Thanh Nguyen Trung ${ }^{1,2, a}$ and Linh Do Thi $^{3}$ \\ ${ }^{1}$ School of Economics, Shanghai University, Shanghai, China, Shanghai 200444 \\ ${ }^{2}$ Faculty of Economics and Business Administration, Community college, Vietnam \\ ${ }^{3}$ Faculty of Accounting and Finance, Hatay Community college, Hanoi, Vietnam \\ anguyen_t_t@sina.com
}

Keywords: Monetary policy; Stock prices; ARDL model.

\begin{abstract}
The sensitivity of the stock market to the monetary policy leading to the study of the impact of monetary policy on stock market is extremely important (For each different market, reactions of stock index also differ. Therefore, this paper is conducted to assess the impact of monetary policy on the stock price index in Vietnam market and Shenzhen (China) from 2006 to 2015. The authors use the ARDL model to find out and compare the impact of monetary policy on stock price in two markets. As a result, it shows that the monetary policies are significant in changing the stock price. In particular, interest rates, money supply and reserved ratio have opposite effects on stock prices in Vietnam; For the Shenzhen market, the reserved ratio have immediate positive impact on the stock price of Shenzhen.
\end{abstract}

\section{Introduction}

The stock market in China began to appear from the 70s of the 19th century, however, until July of 1920; the market really developed and was marked with the establishment of Shanghai Stock exchanges. It is one of largest center in China. Right after that time, there was a consecutive appearance of other stock exchanges such as the stock exchange HuaShang Shanghai, Qingdao commodity exchanges, Tianjin Enterprise Transaction Center \& etc... However, centers operated relatively independently. Only since 12/1990 till 07/1991 when Shanghai Stock Exchange and Shenzhen stock exchanges Shenzhen operated officially, it was marked with the establishment of the central securities market, as well known as the boom period of the Chinese stock market. On $8^{\text {th }}$ Sep, 2006, under the approval of the State Council and management agencies, the exchanges of Shanghai, Suzhou, Dalian, and Shenzhen jointly agreed to establish Chinese Stock exchanges.

Meanwhile, Vietnam's stock market was established in 2000 with the first exchanges Ho Chi Minh Stock Exchange (HOSE). In five years later, Hanoi stock exchanges were founded (HNX). Since 2005 till 2008, the market grew sharply at a record score of 1137.69 points. However, the market plunged freely to 245.74 points due to the heavy impact of the global economic crisis.

In each session, there are tens of millions dollars traded on the Stock Exchange in Vietnam and China. Profits from playing the stock were the main source of income for many investors (Maskay, 2007). The change (degradation) of the stock market will led to the turmoil in investors' lives because it directly relates to their main income. These changes are due to the impact of international market factors (Maskay, 2007) or the monetary policy (macroeconomic) of the state bank. Therefore, the study of impacts of policies especially monetary policy considered as an important key which helps investors to make right decisions.

There have been many studies on fluctuation of the stock price and monetary policy. Most of them approved that stock indices react sensitively to changes of monetary policy (Azali, Zare. \& Habibullah, 2013). Stock Investors always keep their eyes on market's changes in general and the monetary policy of the state bank in particular in order that they can make a right dicision which will bring benefit. Hence, stydying impacts of factors on stock price become a vital part which helps investors to make investing decision. 
Vietnam and China have similar points in terms of economic and geographical position. Therefore; this paper's aim is to compare the influence of monetary policy on stock prices in Vietnam and China from 2006 to 2015.

\section{Theoretical Overview and Research Models}

Theoretical Overview. Monetary policy is a tool to change the operation of the economy in a positive direction towards the development of the country. At the same time, monetary policy is also considered as an important macroeconomic policy (Maskay, 2007). Apart from the impact on inflation (within the allowed limit which is approved by the centre bank to control inflation and supervise bank system), the monetary policy also affects other aspects of the economy such as real GDP , unemployment and exchange rates, the stock market.

Monetary poliies can be conducted in many different tools such as rate policy, interest rates, money supply, open market or the required reserve. (Ali, 2014; Dufour \& Tessier, 2006; Okpara, 2010; Fischbacher, 2012; Zare \& et al, 2013; Gali \& GAMBETTI, 2013; Maskay, 2007; Jamil \& Ulla, 2013; Adjasi \& et al, 2008; Homa \& Jaffe, 1971; Hamburger \& Chochin, 1972; Maskay, 2007; Nofeldt, 2014); Teja et al, 2013). However, for newborn financial markets like Vietnam, the application of the open market is not effective when the transaction is not entirely through banks. Therefore; open market operation seems not to affect to adjust the monetary policy as well as the stock market.

Researching Models. In this research, the author uses the time series data to evaluate the immediate impacts and influctuation at lag period. To solve the researhing aim, the authors refer the previous studies and launch researching model with variables as below:

Tabel 1: Aspect and reference model

\begin{tabular}{ccc}
\hline Variable name & Aspect & Authors \\
\hline Interest rate & - & Ali, 2014; Dufour \& Tessier, 2006; Okpara, 2010; Fischbacher, 2012; Zare \& \\
et al, 2013; Gali \& Gambetti, 2013 \\
Exchang rate & $-/+$ & Maskay, 2007; Jamil \& Ulla, 2013; Adjasi \& et al, 2008 \\
Money Supply & + & Maskay, 2007; Nofeldt, 2014 \\
Required reserve & - & Teja \& ctg, 2013 \\
\hline
\end{tabular}

Source: Authors' collection

With interest rate, exchange rate, money supply and required reserve ratio are chosen as independent variables in the below model:

$$
\begin{aligned}
& \mathrm{VNI}_{\mathrm{t}}=\alpha_{0}+\alpha_{1} * \mathrm{VNI}_{\mathrm{t}-1}+\alpha_{2} * \mathrm{VNI}_{\mathrm{t}-2}+\ldots+\alpha \mathrm{n} * \mathrm{VNI}_{\mathrm{t}-\mathrm{n}}+\beta_{0} * \mathrm{MPi}_{\mathrm{t}}+\beta_{1} * \mathrm{MPi}_{\mathrm{t}-1}+\ldots+\beta \mathrm{n} * \mathrm{MPi}_{\mathrm{t}-\mathrm{n}}+\text { uit } \\
& \mathrm{SHE}_{\mathrm{t}}=\alpha_{0}+\alpha_{1} * \mathrm{SHE}_{\mathrm{t}-1}+\alpha_{2} * \mathrm{SHE}_{\mathrm{t}-2}+\ldots+\alpha \mathrm{n}^{*} \mathrm{SHE}_{\mathrm{t}-\mathrm{n}}+\beta_{0} * \mathrm{MPj}_{\mathrm{t}}+\beta_{1} * \mathrm{MPj}_{\mathrm{t}-1}+\ldots+\beta \mathrm{n} * \mathrm{MPj}_{\mathrm{t}-\mathrm{n}}+\mathrm{ujt} \\
& \text { In Which: Dependent variables: VNI: VNINDEX at time " } \mathrm{t} \text { " } \\
& \text { SHE: Shenzhen price index at time " } \mathrm{t} \text { " } \\
& \text { Independent variables: MPi: Vietnam monetary policy. } \\
& \text { MPj: Chinese monetary policy. } \\
& \text { MP: Interest rate; exchange rate; Money supply; Reserve required }
\end{aligned}
$$

\section{Method}

To estimate impacts of the monetary policy on the stock price, time series data is used so the suitable model chosen for the study is ARDL model. 
For time series data, to ensure sustainable model, before performing ARDL model, researchers in the study used data sources without unit roots (stable data chain). The input data without unit root will eliminate the fake of regression case (Gurajati, 2003; Ramanathan, 2002).

Time series Data without unit roots is a series with constant mean, variance, and covariance at every time (Gurajati, 2003). To test unit roots of time series data, the author use ADF (Gurajati, 2003).

Optimal lag is shown with variables are modeled through the lag variables and the other variables at the same lag level. The determination of the optimal latency is based on selected indicators (Hansen, 2013), these indicators are supported in EViews software.

\section{Results}

\section{Some Number on the Monetary Policy and Stock Prices}

Descriptives. In the period 2006 - 2015 the stock index reached 543.28 points at average; in which the maximum value reached 1137.69 points, the lowest value was 245.74 points. And in recent years, Stock price of Vietnam trends to decrease (Fig 1). Meanwhile, in recent years Shenzhen's stock index tends to rise. (Fig. 2)

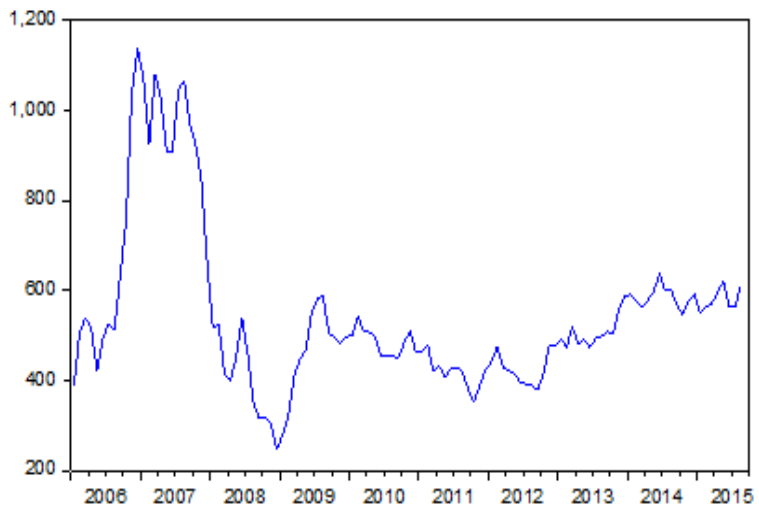

Figure1. Stock price of Viet Nam 2006-2015

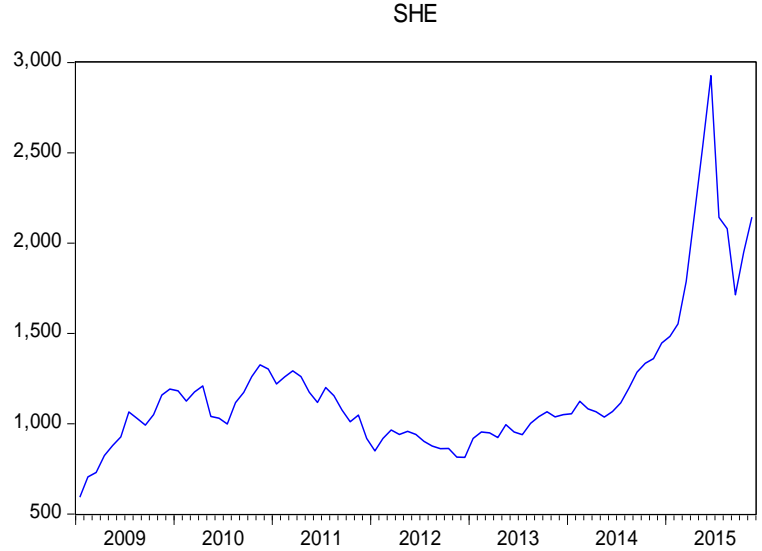

Figure2. Stock price of Shenzhen 2006-2015

Unit root test. To assess the impact of monetary policy on stock prices, the input variables needs to be ensured with data reliability in order to avoid the fake regression; data needs tobe without unit roots (Gujarati, 2003). The test results were obtained as follows: 
Table 2 Testing result for value without unit roots of data series

\begin{tabular}{|c|c|c|c|c|c|c|}
\hline \multirow{2}{*}{ ID } & \multirow{2}{*}{ Variables } & \multirow{2}{*}{$\begin{array}{c}\text { ADF- } \\
\text { statictics }\end{array}$} & \multicolumn{3}{|c|}{ Statistical Value at the levels of significance. } & \multirow{2}{*}{ Prob } \\
\hline & & & $1 \%$ & $5 \%$ & $10 \%$ & \\
\hline \multirow{5}{*}{ VietNam } & LVNI & -2.387 & -3.489 & -2.887 & -2.580 & 0.148 \\
\hline & IR & -2.680 & -3.490 & -2.887 & -2.581 & 0.081 \\
\hline & LEX & -0.515 & -3.489 & -2.887 & -2.580 & 0.883 \\
\hline & LM2 & -2.373 & -3.489 & -2.887 & -2.580 & 0.152 \\
\hline & $\mathrm{RE}$ & -3.388 & -4.067 & -3.462 & -3.157 & 0.060 \\
\hline \multirow{5}{*}{$\begin{array}{c}\text { Shenzhen } \\
\text { China }\end{array}$} & LSHE & -1.4823 & -4.0739 & -3.4655 & -3.1594 & 0.8279 \\
\hline & IR & 1.3740 & -4.0753 & -3.4662 & -3.1598 & 1.0000 \\
\hline & LEX & -3.7486 & -4.0769 & -3.4670 & -3.1602 & 0.0247 \\
\hline & LM2 & -3.8825 & -3.5229 & -2.9018 & -2.5883 & 0.0035 \\
\hline & $\mathrm{RE}$ & -3.5155 & -2.8986 & -2.5866 & 0.4330 & -3.5155 \\
\hline \multicolumn{7}{|c|}{ THE DIFFERENCE } \\
\hline \multirow{5}{*}{ VietNam } & DLVNI & -8.254 & -4.041 & -3.450 & -3.150 & 0.000 \\
\hline & DIR & -6.965 & -4.041 & -3.450 & -3.150 & 0.000 \\
\hline & DLEX & -8.565 & -4.041 & -3.450 & -3.150 & 0.000 \\
\hline & DLM2 & -9.299 & -4.041 & -3.450 & -3.150 & 0.000 \\
\hline & DRE & -4.397 & -4.070 & -3.464 & -3.158 & 0.004 \\
\hline \multirow{3}{*}{$\begin{array}{c}\text { Shenzhen } \\
\text { China }\end{array}$} & DLSHE & -7.2164 & -4.0753 & -3.4662 & -3.1598 & 0.0000 \\
\hline & DIR & -4.4006 & -4.0784 & -3.4677 & -3.1606 & 0.0038 \\
\hline & D2RE & -18.2108 & -3.5155 & -2.8986 & -2.5866 & 0.0001 \\
\hline
\end{tabular}

Source: Eview's results

Results showed that the variables do not stop at the level of significance of $1 \%, 5 \%$ and $10 \%$ so that the author uses the 1 st difference and re-tests then finds out that $1^{\text {st }}$ difference variables are satisfied for conditions of not having unit roots (excluding reserved ratio of Shenzhen at $2^{\text {nd }}$ difereces).

Optimal lag. Results of lag test from the data analysis for the period 2006 - 2015 are shown as follows (Table 3):

Table 3 The result for determining optimal lag

\begin{tabular}{ccccccc}
\hline & Lag & LR & FPE & AIC & SC & HQ \\
\cline { 2 - 7 } & 0 & NA* & 0.007703 & -2.02835 & $-1.889471^{*}$ & -1.97235 \\
\multirow{5}{*}{ Viet Nam } & 1 & 3.195099 & $0.007583^{*}$ & $-2.044164^{*}$ & -1.87751 & $-1.976959^{*}$ \\
& 2 & 0.460385 & 0.007711 & -2.02749 & -1.833059 & -1.94908 \\
& 3 & 0.631352 & 0.007825 & -2.01297 & -1.790761 & -1.92336 \\
& 4 & 0.581014 & 0.007946 & -1.99792 & -1.747936 & -1.89711 \\
\hline \multirow{6}{*}{ SHE } & 0 & 85.30542 & NA & 0.006684 & -2.170417 & $-2.014737^{*}$ \\
& 1 & 86.19325 & 1.631685 & 0.006705 & -2.167385 & -1.980569 \\
& 2 & 86.23996 & 0.084584 & 0.006881 & -2.141620 & -1.923668 \\
& 3 & 89.48311 & $5.785090^{*}$ & $0.006478^{*}$ & $2.202246^{*}$ & -1.953158 \\
& 4 & 89.51193 & 0.050621 & 0.006653 & -2.175998 & -1.895774 \\
\hline
\end{tabular}

Source: Eview's results 
Results showed that the study data sources affect each other in two stages (the impact of monetary policy on stock index immediately in that month and after one month). Thus, the authors choose lag 1 and 3 to establish a research model.

Johansen cointegration Test. To test cointegration between variables (long-term relationship), the autho uses Jonhanse test. The result is as below:

Table 4 Johansen cointegration Test

\begin{tabular}{|c|c|c|c|c|}
\hline & $\begin{array}{l}\text { Hypothesized } \\
\text { No. of CE(s) }\end{array}$ & Eigenvalue & Trace Statistic & Prob.** \\
\hline \multirow{5}{*}{ VietNam } & None $*$ & 0.560 & 149.452 & 0.000 \\
\hline & At most $1 *$ & 0.342 & 76.300 & 0.000 \\
\hline & At most $2 *$ & 0.283 & 39.111 & 0.003 \\
\hline & At most 3 & 0.089 & 9.558 & 0.316 \\
\hline & At most 4 & 0.014 & 1.292 & 0.256 \\
\hline \multirow{5}{*}{ SHE } & None * & 0.356969 & 82.51320 & 0.0035 \\
\hline & At most $1 *$ & 0.258725 & 47.62983 & 0.0525 \\
\hline & At most 2 & 0.161467 & 23.97852 & 0.2013 \\
\hline & At most 3 & 0.118274 & 10.06656 & 0.2756 \\
\hline & At most 4 & 0.001550 & 0.122559 & 0.7263 \\
\hline
\end{tabular}

Source: Eview's results

The authors found two long-term relationships between the variables studied in both Vietnam and SHE (China). This long-term relationship will be estimated in the regression model.

Regression Results. Because reciprocal relationship is not accessed in researching purpose, the author focuses on regression analysis without using Granger test. Final results were obtained as belows:

Table 5: Results of estimating factors' impact on stock price

\begin{tabular}{|c|c|c|c|c|c|c|}
\hline \multicolumn{4}{|c|}{ VNI } & \multicolumn{3}{|c|}{ SHE } \\
\hline & $\beta$ & S.E & Prob & $\beta$ & S.E & Prob \\
\hline $\mathrm{C}$ & 2.095 & 0.768 & 0.006 & 0.010 & 0.008 & 0.1914 \\
\hline $\operatorname{IR}(-1)$ & -0.007 & 0.002 & 0.003 & - & - & - \\
\hline LM2(-1) & -0.055 & 0.021 & 0.009 & - & - & - \\
\hline LM2 & - & - & - & - & - & - \\
\hline $\mathrm{RE}(-1)$ & -0.016 & 0.005 & 0.003 & - & - & - \\
\hline LEX & - & - & - & - & - & - \\
\hline $\mathrm{DIR}_{\mathrm{t}, \mathrm{t}-1}$ & - & - & - & - & - & - \\
\hline $\mathrm{DLM} 2_{\mathrm{t}, \mathrm{t}-1}$ & - & - & - & - & - & - \\
\hline $\mathrm{D} 2 \mathrm{RE}_{\mathrm{t}, \mathrm{t}-1}$ & - & - & - & -0.074 & 0.038 & 0.050 \\
\hline $\mathrm{D} 2 \mathrm{RE}_{\mathrm{t}, \mathrm{t}-2}$ & - & - & - & -0.153 & 0.038 & 0.000 \\
\hline $\operatorname{DLEX}_{\mathrm{t}, \mathrm{t}-1}$ & - & - & - & - & - & - \\
\hline $\mathbf{R}^{\mathbf{2},-1}$ & & $11.11 \%$ & & & $17.51 \%$ & \\
\hline Heteroskedasticity test & & 0.8 & & & 0.3118 & \\
\hline Autocorrelation test & & 0.2 & & & 0.092 & \\
\hline
\end{tabular}

Source: Eview's results

Results showed that monetary policy has the opposite effect on Vietnam stock price through three policy instruments : interest rates, money supply and required reserve ratio ( $p$-value is less than 0.05). However, the effects will have long-term impacts, but in the short-term, monetary policy seems to have no meaning in making the stock price change. 
For the Shenzhen China market, only the required reserve ratio have short-term impact on the stock price. Also required reserve ratio has the opposite effect on the stock price in lag 1 and 2.

\section{Discussion}

The interest rate has negative impacts on Vietnam Stock Market, state banks have tightened the monetary policy by raising interest rates, which in the short term will not affect the stock market, but in the long term it will have negative affect to businesses, especially companies that use large amounts of bank loans for their business operations. The research results of interest rate are compatible with previous studies of Ali, 2014; Dufour \& Tessier, 2006. However, for the Shenzhen market, interest rate has no meaning in changing stock market or in other word; Shenzhen stock market does not depends on the interest rate because of the stability of renminbi during the researching period.

The policy of reserved ratio has opposite effect on Vietnam stock market and Shenzhen stock market. When the Government increases reserved ratio for banks, the amount of money exchanged is limited between banks and individual or businesses. In the short run, businesses can overcome these difficulities by investing; can settle payment by leveraging internal funds or borrowing from external sources. However; in long run, increasing reserved ration will create lot difficulties for businesses; its operation will be interrupted when its fund is not enough

In Vietnam market, Monetary supply policy has the opposite effect on the stock price in the long term. Result of the study has some differences with the study of Maskay, 2007; Nofeldt, 2014. This result is similar to the study of Sprinkel (1964) and Homa \& Jafee (1971). In spite of large money supply, the implementation of projects as well as expansion of business activities to reach these loans are limited. The stagnant ammount in banks leads to economy degradation and falling stock price. In the contex of the economic crisis from 2008 till now, the economy has not really got recoveration so the theory of efficient market theory by Fama is no longer correct.

The graph describe relationship between the money supply and the stock index: the bigger M2 gets, the lower stock price becomes and vice versa (Fig. 3).

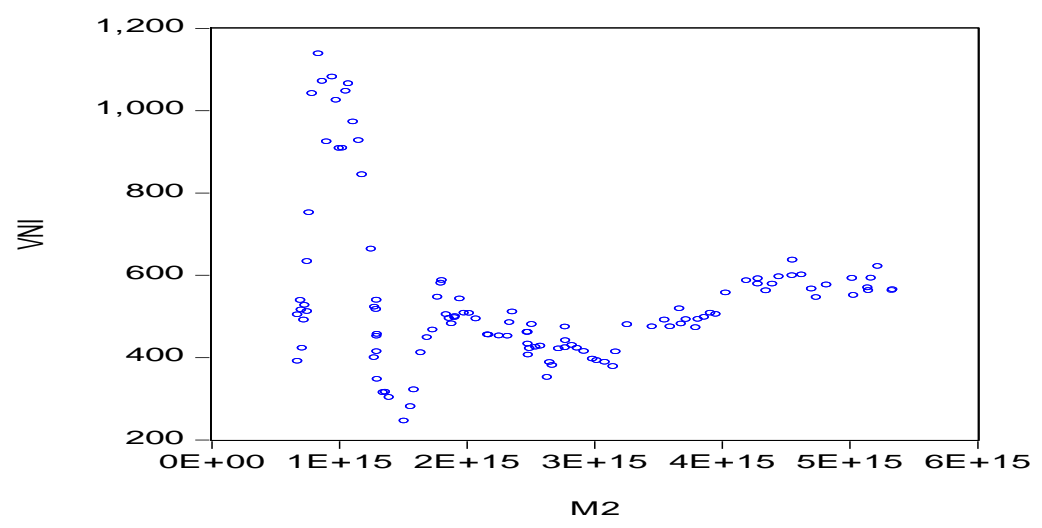

Figure 3. Relationship between money supply and stock price

\section{Conclusion}

The study showed clear results about the effects of monetary policy on both Vienam and Shenzhen Stock Market. Each country has its own economic characteristics, the impact of monetary policy on each stock market also differs. In Vietnam monetary policy has meaning in changing stock market through interest rates, money supply and reserved ratio. However, in the Shenzhen Stock Market market, the reserved ratio has a direct impact on the stock price. However, both countries have one common in using the reserved ratio to regulate the stock market (in the Vietnam Stock Market market, Reserved ratio has impact in long-term and negative on the stock price ; In Shenzhen Stock Market Reserved ratio only impact in short-term in lag 1 and 2. 
The money supply of Vietnam has the opposite effect on the stock price, it indicates that the financial market in Vietnam has not sincerely entered the perfectly competitive market. Other causes are due to the random nature of the data. Therefore, the author hopes following researchers can learn more in order to explain the reasons in more detail and convincing.

\section{References}

[1] Ali, H. (2014), Impact of Interest Rate on Stock Market; Evidence from Pakistani Market, Journal of Business and Management, 16(1), 64-6

[2] Adjasi, C. Harvey, S.K., \& Agyapong. (2008), Effect of Exchange Rate Volatility on the Ghana Stock Exchange, African Journal of Accounting, Economics, Finance and Banking Research, 3(3), 28-47

[3] Dufour, J.M., \& Tessier,D. (2006), Short-Run and Long-Run Causality between Monetary Policy Variables and Stock Prices, Bank of Canada Working paper

[4] Engle, R.F \& Kroner, K.F. (1995), Multivariate simultaneous GARCH, Econometric Theory, 122-150.

[5] Fama, E.F. (1970), Efficient Capital Markets: A Review of Theory and Empirical Work, the Journal of Finance, 25(2), 383-417

[6] Fischbacher, U., Hen, T., \& Zeisberger, S. (2012), the impact of monetary policy on stock market bubbles and trading behavior: evidence from the lab, Journal of Economic Dynamics and Control, 37(10), 2104-2122

[7] Gali, J., \& Gambetti, L. (2013, 2014, 2015), The Effects of Monetary Policy on Stock Market Bubbles Some Evidence, NBER WORKING PAPER SERIES,

[8] Sprinkel, B.W. (1964), Money and Stock Prices. New York: Richard D. Irwin, Home wood, III.

[9] Gurajati, D.N. (2003), Basic Econometrics, McGraw Hill.

[10]Hansen, B.E. (2014), Econometrics, University of Wisconsin.

[11] Homa, K.E., \& Jafee, D.M. (1971), the Supply of Money and Common Stock Prices, the Journal of Finance, 25(5), 1045-1066

[12]Jamil, M., \& Ulla,N. (2013), Impact of Foreign Exchange rate on stock prices, Journal of Business and Management, 7(3), 45-51

[13] Maskay, B. (2007), Analyzing the Effect of Change in Money Supply on Stock Prices, the Park Place Economist, 15, 72-97

[14] Zare, R., Azali, M., \& Habibullah, M.S. (2013), Monetary Policy and Stock Market Volatility in the ASEAN5: Asymmetries over Bull and Bear Markets, International Conference on Economics and Business Research 2013, 18-27

[15]Teja, K.R., Tejaswi, M., Madhavi., \& Ujwala, G. (2013), Cash Reserve Ratio impact on Stock Market (India) in Long run, International Journal of Marketing, Financial Services \& Management Research, 2(8), 85-93

[16] Nofeldt, O. (2014), The effects of Monetary Policy on Stock Market Returns, UMEA University, 1-34

[17]Okpara, G.C. (2010), Monetary Policy and Stock Market Returns: Evidence from Nigeria, Journal Economic, 1(1), 13-21

[18]Ramanathan, R. (2002), Introductory Econometrics with Applications, Harcourt College Publishers. 